\title{
Analysis of the Relationship Between Environmental Degradation of Oil Companies and Economic Growth of Nigeria
}

\author{
Ndubuisi Chinedu Jonathan, Godwin Adaobi Ozioma, Ndah Eze Nwoka \\ Department of Accountancy, Faculty of Management Sciences, Nnamdi Azikiwe University, Awka, Nigeria \\ Email address: \\ ndubuisichinedu758@gmail.com (N. C. Jonathan), adaharry_godwin@yahoo.com (G. A. Ozioma) \\ To cite this article: \\ Ndubuisi Chinedu Jonathan, Godwin Adaobi Ozioma, Ndah Eze Nwoka. Analysis of the Relationship Between Environmental Degradation \\ of Oil Companies and Economic Growth of Nigeria. International Journal of Finance and Banking Research. Vol. 4, No. 4, 2018 , pp. 67-78. \\ doi: $10.11648 /$ j.ijfbr.20180404.11
}

Received: August 1, 2018; Accepted: September 25, 2018; Published: November 5, 2018

\begin{abstract}
When natural resources such as oil and gas are enhanced for economic growth and well-being of the citizenry, the nation invariably finds herself experiencing an array of pollutants including carbon dioxide, warming, and other greenhouse emission. This research therefore is set to analyse the relationship between environmental degradation and economic growth in Nigeria. The objective of the research was decomposed to ascertain if a significant relationship exists between oil spillage and economic growth, gas flaring and economic growth and finally between number of fire outbreaks and economic growth of Nigeria. Descriptive survey research was used and data were collected via Central Bank of Nigeria statistical bulletin and Nigeria National Petroleum Corporation statistical bulletin. The population of the research were the whole oil companies operating in Nigeria. Pearson Coefficient of Correlation was the statistical tool used to analyse the hypotheses and that was done with the aid of Statistical Package for Social Sciences (SPSS). The result of the analysis showed that there is no significant relationship between oil spillage and economic growth, high significant relationship between gas flaring and economic growth and the no significant relationship between number of fire outbreaks and economic growth of Nigeria. The study thus concluded that there is no significant relationship between environmental degradation and economic growth safe for gas flaring which has a high significant relationship with economic growth and recommended among other things that the government should declare a state of emergency on gas flaring by oil companies as it was found to have a very high negative significant relationship with economic growth in Nigeria.
\end{abstract}

Keywords: Environmental Degradation, Economic Growth, Oil Spillage, Gas Flared, Fire Outbreak

\section{Introduction}

The environment according to Word Bank [50] is the natural and social conditions surrounding all mankind including future generations. It is made up of biophysical components and processes of natural environment of terrestrial, marine and celestial. All layers in the atmosphere, inorganic and organic matters, socio-economic components and processes of human endeavours are also considered. According to [34], the environment can justifiably be said to be the natural habitat of man with several components within which various kinds of activities and processes occur. In line with the definition of [27], environment includes water, air, land, and all plants and human beings, or animals living there in and the interrelationships which exist among these or any of them. These elements mentioned here have a symbiotic relationship and any distortion of their natural state could lead to environmental degradation.

Environmental degradation is identified as the deterioration of the environment through depletion of resources such as air, water, and soil, the destruction of ecosystems and the extinction of wildlife [49]. Environmental degradation is said to occur when the environment becomes less valuable or damaged. When habitats are destroyed, biodiversity is lost, or natural resources are depleted, the environment is hurt. Environmental degradation can occur naturally, or through human processes and that the largest areas of concern at 
present are the loss of rain forest, air pollution and smog, ozone depletion, and the destruction of the marine environment [25].

In Nigeria, environmental degradation is evidently seen. Being a developing nation blessed with natural resources such as; natural gas and oil, coal, limestone e.t.c, when these resources are enhanced for economic development and wellbeing of the citizenry, the nation invariable finds herself experiencing an array of pollutants including carbon dioxide, warming and other greenhouse emissions. Etuonovbe asserted that more gas is flared in Nigeria than anywhere else in the world [25]. The smoke released is damaging to people who live nearby such a flare. The flares affect their livelihood and expose them to an increased risk of premature deaths, child respiratory illnesses, asthma and cancer. The flaring produces acid rain in the Niger Delta, which is harmful to vegetation and crops. The smoke is also a major contributor to greenhouse gases. There are periodic incidences of oil spillage in the Niger Delta. Not only does oil spillage cause consequences similar to those caused by gas flaring, but it has caused the instant death of the fish and wildlife population, and also the instant death of human population caused by explosion and fire, as a result of the spillage [25].

These environmental degradations do not only affect the health and the natural environment of a nation but also the economic development of such nation. Sustainable economic development is the type of development that generates economic growth but distributes its benefits equitably, that regenerates the environment rather than destroys it and that empowers people rather than marginalizing them [10]. In the observation of [26] majority of the people in the country continue to dwell in abject penury, despite the fact, that the country is blessed with abundant natural resources which are being harvested on continuing basis by multinational companies and governments. As the process of growth continues, a critical collapse of the world economy due to environmental problems becomes evident. This constitutes a situation in which the success of growth leads to its own demise and generates adverse effects on an economy [43].

The World Bank reported in 1999 that the Niger Delta region has the agricultural potential of feeding the whole of West Africa; today hunger in the area is widespread [39].

The unwarranted poverty in the oil producing states can be traced to the high activity level in the Niger Delta which has exposed the area to dangers of water, land, and air pollution as well as oil spills, which harm aquatic life as well the entire ecosystem, topography, and surface vegetation [29]. Nigeria's Federal Office of Statistics (FOS) revealed that about $50 \%$ of the active labour force engaged one type of agricultural activity or another with yam, cassava, plantain, maize, cocoyam, and vegetables as the main food crops in the Niger Delta [3]. Oil spillage, which eventually leads to germination failure of crops on underutilized farmland, contributes to reduced income from farming, and these issues lead to lower standard of living [18]. Consequently, most farmers are unable to send their children to school. Unarguably, low crop yields of agricultural staples translate to the high cost of food items, such as garri, corn, and cassava, a condition that exacerbates hunger [3].

According to [33] women in the Niger Delta region remain educationally disadvantaged, and the percentage of school enrolment significantly lags behind the median score. The unemployment rate in the region is higher than the national figure $[33,40]$. The collapse of infrastructures in the Niger Delta region is the reason why rural roads are impassable in all seasons of the year, and this contributes to the high cost of moving persons, goods or services in and out to the markets [3]. In the opinion of [10], these effects have led to economic stagnation, agricultural underdevelopment, and poor quality of life due to a lack of essential goods, facilities and funds, isolation, and poor communication. It is estimated that more than half of the inhabitants of the Niger Delta live in rural subsistence characterized by a total absence of such basic facilities as electricity, pipe-borne water, hospitals, proper housing, and roads [28].

Nigeria's dependence on oil and gas extraction has inflicted corresponding costs on the economy and the environment of Nigeria [5, 35]. For more than 50 years, multinational oil companies contaminated a 1,000 square $\mathrm{km}$ (386 sq. mile) area of the Niger Delta region, consequently endangering human health and wildlife [48]. Revenue from oil and gas extraction activities account for $80 \%$ of Nigeria's annual budget while oil accounts for $90 \%$ of its export earnings [8]. The activities of the oil industry have sanctioned environmental degradation in the Niger Delta region and Nigeria as a whole, threatening resource capacity and the economic livelihood of indigenous communities [6]. However, successive Nigerian administrations from the colonial era paid little attention to environmental issues [34].

Generally, speaking problems with environmental degradation are often linked with process of development and therefore have effects on local, regional, as well as global levels. Years of insensitivity to environmental issues or near complete lack of attention to environmental concerns have turned the Niger Delta into one of the most endangered ecosystems in the country. Various forms of ecological activities go on in the region. Prominent among them is oil exploration. This has led to springing up of industries whose activities also generate wastes which are not properly managed and result in environmental pollution.

The general problem is that profits and economic benefits derived from oil and gas businesses have not been used to improve the relationship with stakeholders to mitigate the effects of oil and gas extraction by multinational oil corporations [7]. Therefore the Motivation for this study was rooted in the physical and scientific revelation of the enormous activities of oil companies in Nigeria accompanied with huge profits, but without commensurable plough-back in terms of human, health care and infrastructural developments in spite of the numerous oil man-made health, economic and social challenges confronting the inhabitants. The purpose was to expose how oil activities influence the lifestyles and the health of the people with the hope of making a proactive submission before all stakeholders in 
order to provide adequate commensurate and compensatory measure that will promote the health and holistic acceptable global standards of living of the people.

The questions now according to [11] are: Can economic growth be witnessed without deterioration in the quality of the environment? Does increase in income improves or worsens environmental performance? Would economic growth still remain attractive considering the unfavourable consequences on the environmental quality? These are basically issues encountered when observing the relations between economic growth and environmental quality.

\subsection{Objective of the Study}

The objective of the study is to analyse the relationship between environmental degradation of oil companies and economic development in Nigeria. In specific sense, the study seeks to ascertain:

1. If there is a significant relationship between oil spillage of oil companies and economic growth of Nigeria;

2. If there is a significant relationship between gas flaring of oil companies and economic growth of Nigeria.

3. If there is a significant relationship between fire outbreak from oil companies and economic growth of Nigeria

\subsection{Statement of Research Hypotheses}

The following hypotheses are relevant to the stated objective above and shall be tested in this study:

1. Ho: There is no significant relationship between oil spillage of oil companies and economic growth in Nigeria.

Hi: There is a significant relationship between oil spillage of oil companies and economic growth in Nigeria.

2. Ho: There is no significant relationship between gas flaring of oil companies and economic growth in Nigeria.

$\mathrm{Hi}$ : There is a significant relationship between gas flaring of oil companies and economic growth in Nigeria.

Ho: There is no significant relationship between fire outbreak from oil companies and economic growth in Nigeria

Hi: There is a significant relationship between fire outbreak from oil companies and economic growth in Nigeria

\section{Review of Related Literature}

\subsection{Conceptual Framework}

\section{The Concept of Environmental Degradation}

Environmental degradation According to [34] is the deterioration of the environment through human activities resulting in the depletion of resources, contamination of air, water, and soil, the destruction of the ecosystems and the extinction of flora and fauna (wildlife). They further stated that this could also be any change or disturbance capable of producing harmful effects on the environment i.e social, economic, technological and institutional activities, and consequently producing results that are undesirable for present and future generations. Environmental degradation occurs when earth's natural resources (water, air, soil) are depleted. Environmental degradation constitutes a systemic destruction and depletion of the earth's ecological systems such as water resources, mangroves, plants, and the natural soil and air, which are the source of life [30].

Environmental degradation can be seen as the disintegration of the earth or deterioration of the environment through consumption of assets, for example, air, water and soil; the destruction of environments and the eradication of wildlife. It is characterized as any change or aggravation to nature's turf seen to be pernicious or undesirable. Ecological effect or degradation is created by the consolidation of an effectively substantial and expanding human populace, constantly expanding monetary development or per capita fortune and the application of asset exhausting and polluting technology. It occurs when earth's natural resources are depleted and environment is compromised in the form of extinction of species, pollution in air, water and soil, and rapid growth in population.

Environmental degradation is a concept that is used interchangeably with environmental pollution. According to [1], environmental pollution is the summation of all the various negative environmental effects of human development activities. Pollution may be defined as any introduction by man, directly or indirectly of substance or energy into the environment resulting in deleterious effects of such nature as to endanger human health, harm living resources, ecosystems and material property and impair amenities or interfere with other legitimate uses of environment.

Pollution according to [25] is occurring all over the world and poisoning the planet's oceans and that even in remote areas, the effects of marine degradation are obvious, in some areas, the natural environment has been exposed to hazardous waste and in other places major disasters such as oil spills have ruined the local environment. Human activities and the environment are inter-related. This is because any activity of man is done in the environment and the resultant effect is either positive or negative to man. Human activities are diverse. According to [45], negative effects or man arise from these economic and domestic activities. For instance, agriculture requires pesticides that pollute the atmosphere or enter drainage system via run off and sewers. Other activities which lead to pollution include thermal power stations, burning of fossil fuels, exhaust fumes. All these emit harmful pollutants like sulphur dioxide, carbon monoxide that cause acid rain, global warming, and the malfunctioning of human haemoglobin. Various categories of human activities capable of causing environmental nuisance and the degradation according to [47] are;

i. Destructive logging of forests

ii. Overgrazing and over-cropping of arable lands

iii. Strip mining etc. This may be extended to include oil exploitation, industrialization, improper disposal of domestic solid waste and human excretal including liquid waste, over-utilization of non-degradable materials for packaging among others.

Etuonovbe categorized pollution into three major types: air 
pollution, water pollution and noise pollution. Air pollution is the contamination of the air with unwanted gas, smokes, particles and other substances [25]. Industrial activities are responsible for a wide range of air pollution. Thermal power stations, burning fossil fuel and moving vehicles emit harmful pollutants like sulphur dioxides, nitrogen oxide and carbon dioxide. Water pollution in usually occur as a result of industrial plants liquid discharges, decomposed waste, solid mineral mining activities as well as petroleum mining operations. Noise is most often defined as unwanted sound.

Environmental degradation of oil companies usually come in the form of oil spillage and gas flaring. According to [14], Oil spillage is the leading environmental hazard caused by crude oil exploration in the Niger Delta and constitutes significant economic, ecological, health, social, and political problems in Nigeria, and the Niger Delta in particular. Etuonovbe noted that when there is an oil spill on water, spreading immediately takes place [25]. The gaseous and liquid components evaporate. Some get dissolved in water and even oxidize, and yet some undergo bacterial changes and eventually sink to the bottom by gravitational action. The soil is then contaminated with a gross effect upon the terrestrial life. As the evaporation of the volatile lower molecular weight components affect aerial life, so the dissolution of the less volatile components with the resulting emulsified water, affects aquatic life. On the other hand, Gas flaring is the burning or disposing of waste gases through the use of combustion [22]. Most of the gas flaring that occurs in the Niger Delta region is around oil wells that are close to farmlands and dwelling homes.

\section{Economic Growth}

Economic growth is an increase in the capacity of an economy to produce goods and services, compared from one period of time to another. It can be measured in nominal or real terms, the latter of which is adjusted for inflation. Traditionally, aggregate economic growth is measured in terms of gross national product (GNP) or gross domestic product (GDP), although alternative metrics are sometimes used. Wikipedia defined economic growth is the increase in the inflation-adjusted market value of the goods and services produced by an economy over time [49]. It is conventionally measured as the percent rate of increase in real gross domestic product, or real GDP. According to [19], economic growth is the process by which a nation's wealth increases over time. Although the term is often used in discussions of short-term economic performance, in the context of economic theory it generally refers to an increase in wealth over an extended period. From the above definitions, two major things stand out in the definition of economic growth: increase in a nation's wealth or goods and services produced and the increase would be for a period of time.

Growth is usually calculated in real terms - i.e., inflationadjusted terms - to eliminate the distorting effect of inflation on the price of goods produced. Measurement of economic growth uses national income accounting. Since economic growth is measured as the annual percent change of gross domestic product (GDP), it has all the advantages and drawbacks of that measure. The economic growth rates of nations are commonly compared using the ratio of the GDP to population or per-capita income. The economic growth rate is calculated from data on GDP estimated by countries' statistical agencies. The rate of growth of GDP/capita is calculated from data on GDP and people for the initial and final periods included in the analysis of the analyst. Economic growth is usually distinguished from economic development, the latter term being restricted to economies that are close to the subsistence level. The term economic growth is applied to economies already experiencing rising per capita incomes.

\section{Oil Companies}

The name Multinational Oil Corporations to refer to companies engaged in oil and gas extraction activities that operate under a system of decision-making that permits coherent policies and a common strategy and that control entities in more than one country [25].

\section{Oil Spillage}

Etuonovbe stated that when there is an oil spill on water, spreading immediately takes place [25]. The gaseous and liquid components evaporate. Some get dissolved in water and even oxidize, and yet some undergo bacterial changes and eventually sink to the bottom by gravitational action. As the evaporation of the volatile lower molecular weight components affect aerial life, so the dissolution of the less volatile components with the resulting emulsified water, affects aquatic life. Fish contaminated by oil cause sickness among the people and further economic ruin as fish stocks decline. He further stated that spillages are a regular feature of life in the Delta, they are rarely dealt with promptly and in some cases, minor leaks are left for months, resulting in major pollution. The chemical compound from industrial polluted areas causes respiratory and chromosome damage in women. Moreover, it causes still births and cancer in women [46]. According to [14] oil spillage is the leading environmental hazard caused by crude oil exploration in the Niger Delta and constitutes significant economic, ecological, health, social, and political problems in Nigeria, and the Niger Delta in particular. Duru noted that oil spills may result from operational mishaps, equipment failure, and sabotage [20]. In an environment that is aquatic, the oil sometimes flows on the water surface, encroaching shorelines by wind and wave actions invariably affecting the soil [38].

Imobighe noted that in 1979, a storage facility at West Niger Delta, a Shell operated Forcados terminal, collapsed and spilled approximately 560,000 barrels into the surrounding land, mangroves swamps, and the Atlantic Ocean and that in the 40 years of oil exploration in Nigeria, the Directorate of Petroleum Resources now the Department of Petroleum Resources (DPR) recorded over 6,000 spills with an average of 150 annually [29]. In the same vein [14] stated that in the period from 1976-1996, 647 incidents occurred resulting in the spillage of $2,369,000$ barrels of crude oil and of this oil spillage, 549,000 barrels were recovered while $1,820,410$ barrels dissolved into the ecosystem. As a result of this spillage, the soil is 
contaminated with a gross effect upon the terrestrial life and farmland polluted by oil is rarely rehabilitated, destroying livelihoods [25].

According to [12] poorly designed causeways and canals used by the oil industry affect the hydrology of the seasonally flooded freshwater swamp and the brackish water of the mangrove forest, killing crops, destroying fishing grounds, and damaging drinking water supplies. They further stated that dredging of creeks by Multinational Oil Corporations has significantly altered the landscape, thereby causing soil erosion and houses to collapse. Pollution due to oil well blow out, corrosion of pipelines and vandalism can lead to underground leakages, which threaten the environment in the form of soil pollution and destruction of vegetation [14]. Etuonovbe noted that leaking pipelines, running through villages, farms, creeks and rivers in the Niger Delta, are a major source of pollution, sickness and economic ruin for the people of the Niger Delta [25]. In 1980, a significant pipeline blowout spewed some 200,000 barrels of crude oil into the Atlantic Ocean and destroyed over 840 acres of Niger Delta mangrove [29]. The cumulative effect of repeated but smallscale oil spills is just as potentially dangerous to the affected site as any isolated large oil spill [38]. The negative impact of oil spills and gas flaring in Niger Delta have probably placed the survival of endangered species, such as the Delta elephant and the white crescent monkey, at greater risk in addition to devastating the largest mangrove forest in Africa and the body of water in the region [24].

5. Gas Flaring

Gas flaring according to [23] is defined as the process of separating and burning of the gas produced from pumped oil resource from the ground. This is done by burning the separated gas in massive flares as waste into the air/ environment [41]. Gas flaring is the burning or disposing of waste gases through the use of combustion [22]. Duru stated that one of the main types and causes of environmental degradation in the Niger Delta is the result of gas flaring and that most of the gas flaring that occurs in the Niger Delta region is around oil wells that are close to farmlands and dwelling homes [20]. Edino et al noted that the 56.6 million metric tons of associated gas flared daily in Nigeria are equivalent to about $16 \%$ of the total gas flared in the world and that the environmental damage is yet to be fully estimated, but anecdotal evidence suggests it is equally colossal [21]. Consequently, the oil firms in Nigeria account for more greenhouse gas emissions than all other sources in sub-Saharan Africa combined [32]. Bayode et al argued that gas flaring contributes to climate change, which may portend enormous risk for Nigeria and the world [18].

Carcinogens with serious health concern for the residents of the region represent many of the by-products of gas flares [22]. Crops cultivated on farmlands produced low yields, and their nutrient statuses are reduced due to the closeness to gas flaring sites [22]. Consequently, the result of gas flaring is that communities observe a continual bright light, making it difficult to distinguish night from day and that constant deafening noises caused by hardware on the site, dehydration and heat waves from gas flares exacerbate this situation [37]. In oil and gas production, emitters of air pollutants include trans-shipment stations, maritime floating port terminals, drilling platforms, crude oil recovering platforms, linking platforms, water injection platforms, pumping platforms, shelter platforms, telecommunication platforms, crude oil measurement platforms, and flaring platforms [44]. Duru noted that the cost of gas flaring is significant when calculated in monetary terms [20]. Babatunde suggested that gas flaring in Nigeria costs the nation about $\$ 12.5$ million annually [17].

\subsection{Theoretical Framework}

This study reviewed Environmental Cost Reduction Theory, Eco-Efficiency Theory and Environmental Kuznets Curve theory.

1. Environmental Cost Reduction Theory: This theory was developed by freeman in1984. It suggests that the lowest environmental costs will be attained at the point of zerodamage to the environment. It is considered that before environmental costs information can be provided, environmental costs must be defined. Environmental quality model is the ideal state of zero-damage to the environment, which is analogous to environmental quality management (EQM), a zero-defect state of total quality management. This is certainly compatible with the concept of eco-efficiency. Environmental costs incurred are costs arising because poor environmental quality exists or may exist and these have to prevented, reduced and remedied.

2. Eco-Efficiency Theory: The concept of eco-efficiency was first described by Schaltegger and Sturm in 1989 and then widely publicized in 1992 by Schmidheiny. Since then it has been accepted as the key strategic theme for global business in relation to commitments and activities directed at sustainable development. The eco-efficiency was described as being achieved by the delivery of competitively priced goods and services that satisfy human needs and bring quality of life, while progressively reducing ecological impacts and resource intensity throughout the life cycle, to a level at least in line with the Earth's estimated carrying capacity.

The concept's practical and theoretical importance lies in its ability to combine performance along two of the three axes of sustainable development, environment and economics. Issues concerning equity and other social properties are not included in the concept of eco-efficiency. Eco-efficiency is fundamentally a ratio of some measure of economic value added to some measure of environmental impact. The higher the value added, the more efficient is the use of environmental services. Alternately, some invert the ratio, which then generally becomes known as eco-intensity. Aerts et al stated that this concept suggests at least three important messages, firstly, improving ecological and economic performance which should be seen as complimentary. Secondly, that improving environmental performance should not be viewed as charity and goodwill but a matter of competitive necessity. A third suggestion is 
that eco-efficiency should be seen as supportive of sustainable development [2].

3. Environmental Kuznets Curve (EKC) Theory: In economics, a Kuznets curve graphs the hypothesis that as an economy develops, market forces first increase and then decrease economic inequality. The hypothesis was first advanced by economist Simon Kuznets in the 1950s and '60s.

The EKC hypothesis postulates an inverted U-shaped relationship between environmental degradation and income per capita. In other words, environmental degradation is expected to increase with income up to a certain threshold beyond which environmental quality will be enhanced by higher income per capita.

Akpan, \& Chuku asserted that the logic of the EKC is intuitively appealing: in the early stages of industrialization, pollution grows more rapidly because high priority is given to increasing material output, and people are more interested in income than environment [9]. The rapid growth inevitably leads to higher utilization of natural resources and thus higher emissions of pollutants, which in turn worsens the environmental conditions. However, at the later stage of industrialization and as income increases, the willingness to pay for a clean environment increases by a greater proportion than income; regulatory institutions become more effective for the environment and pollution levels starts to fall [31]. This tends to suggest that instead of being a threat to the environment, economic growth could be compatible with environmental improvements in the long run as countries could eventually "grow themselves" out of their environmental problems.

\subsection{Empirical Review}

Bayode et al appraised the implications of oil exploration and exploitation in the coastal region of Ondo State [18]. Data used in the study were obtained through physical verification, regular observations, constant monitoring, documentation and records of oral history and administration of questionnaire in some selected settlements in the region. The study highlighted several direct environmental and associated problems that emanated from oil exploration and exploitation in the region. The problems identified among others included large-scale environmental pollution and degradation of agricultural land which serves as source of income for the people coupled with social unrest arising from unpaid claims of compensation and lack of concern for the people in the exploration area. The study advocated for oil spill management plan, control and clearance of spills; giving concessions to indigenous oil companies during bidding process by granting licenses to operate in the Niger-Delta region; adoption of long-term monitoring and surveillance mechanism; continuous provision of infrastructure for the host communities by prospecting oil companies; and development of national oil spill contingency plan among others with a view to guarantee sustainable development of the environment in the region.

Ogboru \& Anga examined the effects of environmental degradation and the risk or threat it poses to sustainable economic development in Nigeria [34]. The study adopted the theoretical approach in the evaluation of the effects of environmental degradation on Nigeria and its implication for sustainable economic development. The study posited that a high number of cases of diseases such as cancer, tuberculosis, viral diseases etc. are consequences of environmental pollution which poses great challenge to sustainable economic development among others. Cases of floods, erosions and drastic drop in agricultural output as a result of environmental degradation were also identified. The study therefore submitted that since our national development policy objective is to achieve rapid economic growth and improvement in individual welfare on a sustainable basis a range of enabling policies, economic instruments and incentives are required to propel this development process in the desired direction.

Adebiyi et al studied the prevention of environmental degradation in Nigeria as a strategy towards sustainable development [1]. The methodology of the study was literature review, with the sole aim of mitigating the Nigerian environmental degradation, resulting from the devastating exploitation of the natural resources occasioned by the ever rising insatiable propensity for economic and technological development. The study revealed that major contributions to the degradation of the Nigerian physical environment to include deforestation and desertification; industrial manufacturing; construction activities; solid mineral extraction; and crude oil exploration and exploitation. Some of the resultant effects of such degradation, as revealed by the study included loss of farmlands, destruction of ecosystems, flooding, landslide and global warming. The study concluded that there was the urgent need for Man to moderate the excessive devastation of the environment due to his inordinate quest for economic and technological development; if he was to protect himself from the foreseeable fatal consequences of continued devastation and that Nigeria, as an integral part of the Earth-World, could not afford to be indifferent. Recommendations included creation of environmental awareness for the citizenry to understand the need to sustain the environment, for the environment to sustain Man. Tripartite collaboration, that is, government agencies, non-governmental organizations and private sectors need to work more closely to promote a sustainable Nigerian environment.

Araoye et al examined the effect of environmental pollution on economic growth in Nigeria [13]. It specifically examined the trend of economic growth and the effect of environmental cost of pollution on economic growth for the period 2000 to 2014 . The study made use of secondary time series data which were obtained from Central Bank of Nigeria statistical bulletin. The data was analyzed using ordinary least square (OLS). Descriptive Statistics was used for the Trend Analysis. The findings of the study showed insignificant impact of pollution cost on economic growth in Nigeria. The study recommended that fine and penalty for oil spillage and gas flaring should be increased to an amount that out rightly discourages oil companies from gas flaring. 
Ayoola examined the theoretical framework for gas flaring and its implication for environmental accounting in the Nigerian Petroleum Industry [16]. Data were sourced from the annual reports of companies involved in gas flaring in the oil and gas industry and the result revealed that the issue plaguing environmental accounting disclosures relate to lack of a standardized requirement for disclosure, political will for legislation, enforcement and the allocation of environmental costs, therefore, the study recommended the development of an integrated corporate environmental policy with legal backing that will streamline environmental information disclosures in annual accounts.

Okpako investigated the influence of oil activities on the socio-economic and environmental health of host communities in Delta-State [36]. The study was motivated by series of observable environmental degradation such as land depletion, pollution occurrence which usually lead to very poor farm yields, low income base, famine and starvation. Three null hypotheses were formulated to guide the study employing the descriptive survey research design method. The target population was made up of all the inhabitants of the 17 local government area of oil producing communities in the state concentrating on the indigenous inhabitants, few oil workers and health personnel with a sample size of 400 participants selected using the purposive random sampling technique. Self-structured questionnaires was the main instrument employed while data collected were analyzed with percentage for personal data of respondents and inferential statistics of X2 set at.05 alpha level for the hypothesized variables. Based on the findings, it was concluded that oil activities in Delta-State have strong negative influence on the variables tested and uncheckmated too. It was therefore recommended amongst others that oil companies, Federal and state governments embark on compensatory empowerment of all host community members especially the youths and women, free medical care for the elderly and other social services for the entire communities.

Akankali \& Nwafili evaluated the impact of crude oil pollution on aquaculture, with the objective of assessing its impacts and the extent of the identified impacts socioeconomically [4]. Data were obtained from a total of 150 fish farmers in five communities of Gokana LGA of Rivers State, Nigeria using structured questionnaires. The study established that crude oil pollution has adverse and severe socio-economic impacts on fish farming. The results of the study also showed that, crude oil pollution led to increased fish mortality rates, reduced yield and general poor quality of cultured fishes. The Kendall's coefficient of concordance, W was 0.97 , indicating high degree of agreement among respondents. Recommendations based on the findings include the provision of more accessible means of information about the adverse consequences of oil pollution to the local communities in particular, educating the people on the socio-economic impact of crude oil pollution and the effects of consuming aquatic resources from polluted waters on the health of humans. Best practices for spill and pollution abatement/prevention including quick response to spill site and mobilizing communities through Global Memorandum of Understanding (GMoU) model to take more direct responsibility for monitoring oil theft and sabotage were recommended to be implemented by the crude oil producing companies within the Niger Delta region, as a means of abating the negative effects of crude oil pollutants adversely impacting aquaculture.

Omorede assessed the impact of oil and gas resource exploration on the environment of Delta State oil producing communities of Nigeria [41]. The study examined the problems associated with Oil exploration and its mitigation. Primary and Secondary data were used to source data for the set objectives. The theoretical framework was based on the resource curse theory and the environmental externalities theory. The study established that various problems such as oil spillage, retardation of vegetation growth, soil infertility, ill-health to members of the community, displacement of the people of the area, constant protestation of host communities, socio-economic deprivation, and perceived marginalization of the people are associated with oil resource exploration. This research concludes that the oil bearing communities have not adequately been compensated for harm done them through degradation of the ecosystem caused by several years of oil exploration. Their oil resource wealth has been turned to oil resource curse as they are disempowered, and condemned to perpetual underdevelopment. The study recommended that Federal Government should exert maximum efforts in assuring strict compliance of its legal instruments by the oil participating industries for a sustainable development in the region.

Oyebamiji \& Mba assessed the effects of oil spillage on community development in the Niger Delta Region of Nigeria with a view to determine its adverse effects on poverty and hunger and its eradication in the region [42]. The concepts of oil spillage, community development, poverty and hunger were reviewed. Three research questions were formulated and analyzed. The instruments used for data collection were the questionnaire, focus group discussions and observation. The face and content validity was tested and also the reliability. Research assistants were used to administer the 15 items questionnaire while the focus group discussions and observations were done by the researchers. The data was analyzed using percentages and weighted mean. The modified likert scale was used to assign values and criterion mean of 2.50 to analyze the research questions. The results of the study showed that the causes and effects of oil spillage were the same in the oil producing states; poverty in the community caused by oil spillage has led to environmental degradation; poverty rate was still on the increase due to poor health as the children are malnourished; the rate of youth unemployment was high and there was no evidence of the national food security in the communities. The study concluded by stating that achieving millennium development goal was still a mirage in this region and that it will take the efforts of the oil companies, government and community members to institute control measures on oil spillages.

Atubi examined the factors of environmental degradation 
in oil producing communities of Delta State, Nigeria [15]. Results showed that $95.2 \%$ of the people had experienced environmental degradation from the oil producing communities and some agreed that most of the effects are still on-going. The study revealed that overall major cause of environmental degradation in all the oil producing communities was the negligence of duty by government agencies charged with oversight duties of monitoring and compliance (30.8\%), Neglect of Environmental regulations/compliance (26.8\%), corruption (23.6\%), lack of Environmental Impact Assessment (EIA) reports from companies either at the beginning of the project or periodic assessment (14.7\%) respectively. The data collected were analyzed using the multiple regression analysis (MRA). From the analysis oil spillage mode explained $100 \%$ while in the case of gas flaring the model explained $74.39 \%$ at $<0.05$. The study recommended among other things that there should be a modification in the current regulatory framework of gas flaring and holistic approach to the environment of planning, development and management of land resources.

\subsection{Gap in Literature}

The empirical literatures reviewed above revealed that several researchers have attempted to establish the link between environmental degradation and economic growth. Notably among these studies in Nigeria were: [18] appraised the implications of oil exploration and exploitation in the coastal region of Ondo State; [34] examined the effects of environmental degradation and the risk or threat it poses to sustainable economic development in Nigeria; [1] studied the prevention of environmental degradation in Nigeria as a strategy towards sustainable development; [13] examined the effect of environmental pollution on economic growth in Nigeria; [16] examined the theoretical framework for gas flaring and its implication for environmental accounting in the Nigerian Petroleum Industry. Most of the researches in this direction were literature based and the few that were statistically based made use of one or two independent variables and had 2014 as its last data date. This study hence filled the gap in literature by studying environmental degradation beyond just oil spillage and gas flaring but also integrated the issues of fire outbreak. The study also updated the data of the study to the last available data (2016) published by the relevant organisations as at the time of writing this research. This study was narrowed down to just oil companies in Nigeria; manufacturing companies were excluded from the research.

\section{Methodology}

\subsection{Research Design}

A research design specifies the methods and procedures for acquiring the information needed to structure and solve the research problems and stipulates what information is to be collected, from what sources, and by what procedures. A good research design ensures that the information obtained is relevant to the research problem, and that it is collected by objective and economical procedures. This study is a descriptive and quantitative type of survey in nature. This is because it provides an accurate description or picture of a particular situation or phenomenon at one or more points in time. This approach aimed at collecting data on, and describing in a systematic manner, the characteristics, features or facts about a given population. It is aimed at describing certain variables in relation to the population.

In determining the relationship between environmental degradation and economic growth among the oil companies in Nigeria, the study made use of descriptive content analysis technique as a means of eliciting data from Central Bank of Nigeria (CBN) statistical bulletin and Nigerian National Petroleum Corporation (NNPC) annual statistical bulletin.

\subsection{Population of the Study}

The population of this study is made up of the ninety eight (98) oil companies currently listed on the Nigeria Stock Exchange.

\subsection{Method of Data Collection}

The data used for this study were secondary data derived from CBN statistical bulletin and NNPC statistical bulletin. This study also made use of books and other related materials especially the Nigerian Stock Exchange fact book.

\subsection{Definition of Variables/Proxies}

Table 1. Definition of variables/Proxies.

\begin{tabular}{ll}
\hline Economic Growth Variables & Definition \\
Gross Domestic Product (GDP) & Nominal GDP adjusted for inflation. i.e real GDP \\
Environmental Degradation variables & Definition \\
Oil Spillage & Total quantity of oil spilled as a result of pipeline product loss and pipeline incidences measured in barrels (bbls) \\
Gas Flaring & Total quantity of gas flared, measured in thousand standard cubic feet (mscf) \\
Fire Outbreaks & Total number of fire outbreak cases \\
\hline
\end{tabular}

\subsection{Method of Data Analysis}

The Pearson product coefficient of correlation (r) was used in analysing and interpreting data connected with the main variables of the hypothesis. The interpretation of the result of $\mathrm{r}$ is that when $\mathrm{r}=0$, there is no relationship between the variables tested. When $0<\mathrm{r}<0.4$, there is weak correlation between the variables and when $r \geq 0.5$ then there is a strong correlation between the variables. When $r$ is negative the (-) 
the variables are inversely related and if positive $(+)$ the variables are directly related.

A reliability test was done on the result of the data analysis by means of a test of significance in order to determine the reliability of the findings and further justify the result of the correlation test done.

The test of significance was used to justify the results. The decision rule here is that once the $r$ calculated ( $r$-cal) is greater than the $r$ tabulated ( $r$-tab) value at a chosen significance level and at a given degree of freedom, We would then reject Ho and accept Hi otherwise we accept $\mathrm{H} 0$ and reject $\mathrm{H} 1$.

The chosen significance level is $99 \%$ ( $\mathrm{P}$ value $=0.01$ ).

However, the analysis of data was not manually done rather this was computed with the aid of the Statistical Packages for Social Sciences (SPSS) version 20.0

\section{Data Presentation and Analysis}

\subsection{Presentation of Data}

Table 2. Environmental Degradation and Economic Growth Variables.

\begin{tabular}{llll}
\hline Year & GDP Figure & Oil Spillage (000'Metric tons) & Gas Flared (mscf) \\
\hline 2007 & $42,922.41$ & 242.23 & $759,688,726$ \\
2008 & $46,012.52$ & 191.62 & $619,398,854$ \\
2009 & $49,856.10$ & 110.38 & $509,351,905$ \\
2010 & $54,612.26$ & 194.42 & $581,568,354$ \\
2011 & $57,511.04$ & 157.81 & $619,032,858$ \\
2012 & $59,929.89$ & 181.67 & $588,666,724$ \\
2013 & $63,218.72$ & 327.48 & $409,311,430$ \\
2014 & $67,152.79$ & 355.69 & $285,761,600$ \\
2015 & $69,023.93$ & 482.81 & $341,372,264$ \\
2016 & $67,931.24$ & $(80.93)$ & $312,448,053$ \\
\hline
\end{tabular}

Source: CBN 2016 Annual Statistical Bulletin \& NNPC 2016 Annual Statistical Bulletin

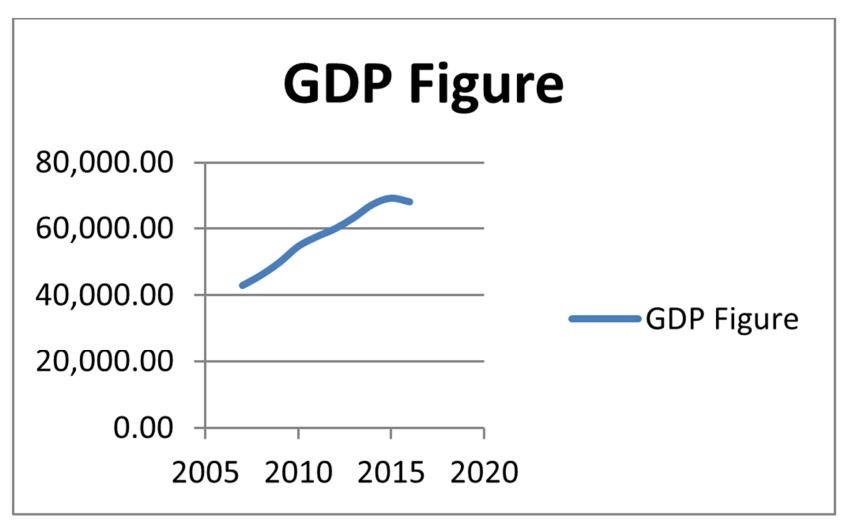

Figure 1. Graphical representation of GDP figure.

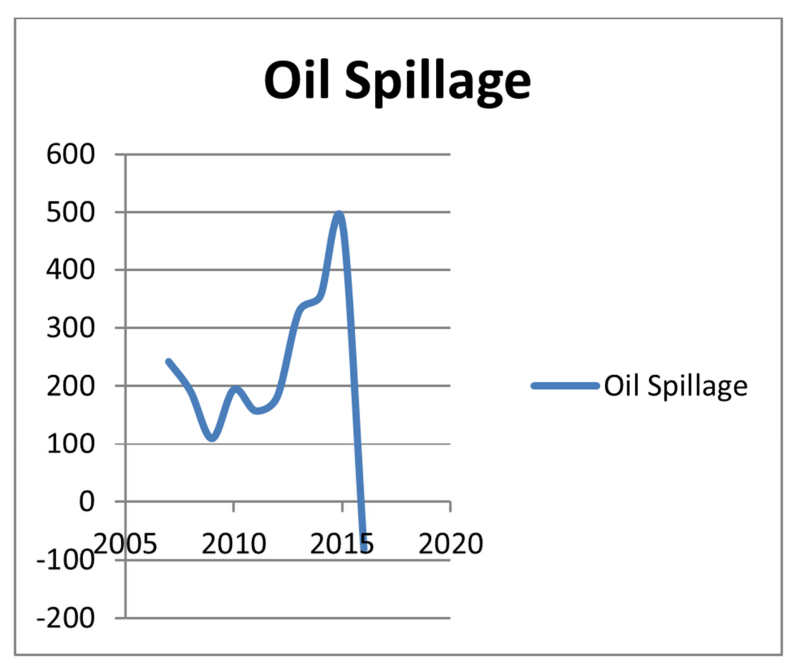

Figure 2. Graphical representation of Oil Spillage.

\section{Gas Flared (mscf)}

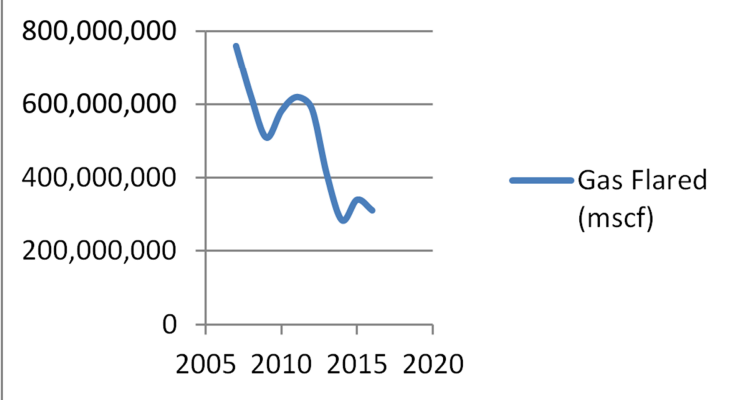

Figure 3. Graphical representation of Gas Flared.

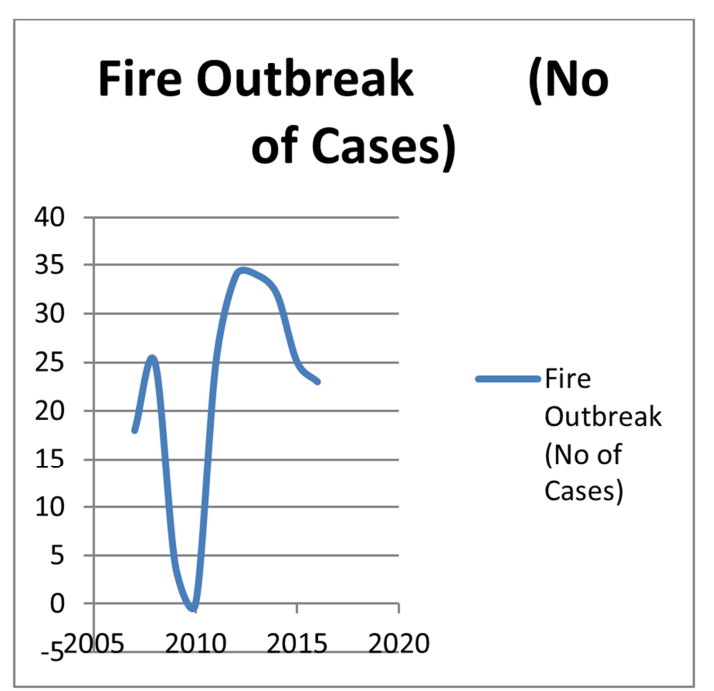

Figure 4. Graphical representation of fire outbreaks. 


\subsection{Test of Hypotheses}

Hypothesis One

Ho: There is no significant relationship between oil spillage of oil companies and economic growth in Nigeria.

Hi: There is a significant relationship between oil spillage of oil companies and economic growth in Nigeria.

Table 3. Correlations between GDP and Oil Spillage.

\begin{tabular}{llll}
\hline & & gdp & Oilspillage \\
\hline \multirow{3}{*}{ Gdp } & Pearson Correlation & 1 & .207 \\
& Sig. (2-tailed) & & .566 \\
& $\mathrm{~N}$ & 10 & 10 \\
\multirow{5}{*}{ Oilspillage } & Pearson Correlation & .207 & 1 \\
& Sig. (2-tailed) & .566 & \\
& $\mathrm{~N}$ & 10 & 10 \\
\hline
\end{tabular}

From the correlation result, oil spillage has a weak positive correlation of.207 with GDP. This implies that the quantity of oil spilled by oil companies only has a weak positive relationship on economic growth in Nigeria. This also implies that an increase in oil spilled will lead to only a less than proportionate increase in economic growth.

DECISION: Since the computed correlation coefficient r.207 is less than the critical $r$ value 765 for two-tailed test at 0.01 level of significance, we therefore accept the null hypothesis and reject the alternate hypothesis, meaning that, there is no significant relationship between oil spillage of oil companies and economic growth in Nigeria.

Hypothesis Two

Ho: There is no significant relationship between gas flaring of oil companies and economic growth in Nigeria.

Hi: There is a significant relationship between gas flaring of oil companies and economic growth in Nigeria.

Table 4. Correlations between GDP and Gas Flared.

\begin{tabular}{llll}
\hline & & Gdp & Gasflared \\
\hline \multirow{3}{*}{ Gdp } & Pearson Correlation & 1 & $-.876^{* *}$ \\
& Sig. (2-tailed) & & .001 \\
& $\mathrm{~N}$ & 10 & 10 \\
\multirow{4}{*}{ gasflared } & Pearson Correlation & $-.876^{* *}$ & 1 \\
& Sig. (2-tailed) & .001 & \\
& $\mathrm{~N}$ & 10 & 10 \\
\hline
\end{tabular}

**. Correlation is significant at the 0.01 level (2-tailed).

From the correlation result, gas flaring has a strong negative correlation of -.876 with GDP. This implies that the amount of gas flared by oil companies has a strong negative relationship on economic growth in Nigeria. This also implies that a decrease in gas flared will lead to a more than proportionate increase in economic growth.

DECISION: Since the computed correlation coefficient $r$ .876 is higher than the critical $\mathrm{r}$ value -.765 for two-tailed test at 0.01 level of significance, we therefore reject the null hypothesis and accept the alternate hypothesis, meaning that, there is a significant relationship between gas flaring of oil companies and economic growth in Nigeria.

Hypothesis Three

HO: There is no significant relationship between fire outbreak from oil companies and economic growth in Nigeria

Hi: There is a significant relationship between fire outbreak from oil companies and economic growth in Nigeria

Table 5. Correlations between GDP and Fire Outbreaks.

\begin{tabular}{llll}
\hline & gdp & Fireoutbreak \\
\hline \multirow{3}{*}{ Gdp } & Pearson Correlation & 1 & .471 \\
& Sig. (2-tailed) & & .169 \\
& N & 10 & 10 \\
Fireoutbreak & Pearson Correlation & .471 & 1 \\
& Sig. (2-tailed) & .169 & \\
& N & 10 & 10 \\
\hline
\end{tabular}

From the correlation result, fire outbreak has a positive correlation of.471 with GDP. This implies that the number of cases of fire outbreak by oil companies has a positive relationship on economic growth in Nigeria. This also implies that an increase in fire outbreak will lead to a less than proportionate increase in economic growth.

DECISION: Since the computed correlation coefficient r.471 is less than the critical $r$ value. 765 for two-tailed test at 0.01 level of significance, we therefore accept the null hypothesis and reject the alternate hypothesis, meaning that, there is no significant relationship between fire outbreak by oil companies and economic growth in Nigeria.

\section{Summary of Findings, Conclusion and Recommendations}

\subsection{Summary of Findings}

From the results of the correlation coefficient of the different hypotheses, the study found the following:

1. There is no significant relationship between oil spillage of oil companies and economic growth in Nigeria.

2. There is a significant relationship between gas flaring of oil companies and economic growth in Nigeria.

3. There is no significant relationship between fire outbreak from oil companies and economic growth in Nigeria.

\subsection{Conclusions}

Previous studies have set out the complexity of the relationship between economic growth and environment, and the role of environmental policy in delivering environmental outcomes, such that the synergies with economic growth are maximised and that put the economy on an environmentally sustainable growth path. The relationship between economic growth and the environment is determined by a number of drivers and achieving sustained growth will require decoupling economic growth from its environmental impacts, not just nationally but globally.

This study investigated the relationship between environmental degradation of oil and gas companies and economic growth in Nigeria. The key variables used to proxy environmental degradation were quantity of gas flared, quantity of oil spilled and number of cases of fire outbreak as 
a result of oil exploration, exploitation and transportation of oil. GDP was used as proxy for economic growth.

This study concluded that oil spillage and fire outbreak does not have significant relationship with economic growth in Nigeria, but gas flaring has a high negative significant relationship with economic growth.

\subsection{Recommendations}

Based on the findings of the study, the following recommendations were made:

1. The government should place a state of emergency on gas flaring by oil companies as it was found to have a very high negative significant relationship with economic growth in Nigeria.

2. The fine and penalty for oil spillage and gas flaring should be increased to an amount that out rightly discourages oil companies from flaring gas.

3. The huge profits made from the sale of crude should be plough back into the economy by way of salvaging or providing a comfortable alternative or compensation for the degraded environment.

4. Government should establish polices and agencies that make sure oil and gas companies clean up after pollution.

5. Agencies responsible for environmental protection and regulations should embrace global environmental best practices and should enforce for efficiently environmental regulations.

\section{References}

[1] Adebiyi, H. O., Oladimeji, A. B., \& Gambo, M. D. (2017). Prevention of environmental degradation in Nigeria: a strategy towards sustainable development. International Journal of Sciences, Engineering \& Environmental Technology, 2 (3), 1724.

[2] Aerts, W., Cormier, D., \& Magnan, M. (2006). Intra-industry imitation in corporate environmental reporting: An international perspective. Journal of Accounting and Public Policy, 25 (3), 299-331.

[3] Afinotan, L. A., \& Ojakorotu, V. (2009). The Niger Delta crisis: Issues, challenges and prospects. African Journal of Political Science and International Relations, 3, 191-198. Available from http://academicjournals.org/AJPSIR.

[4] Akankali, J. A., \& Nwafili, S. A. (2017). An assessment of the socioeconomic impact of crude oil pollution on aquaculture in gokana local government area rivers state, Nigeria. Nigerian Journal of Fisheries and Aquaculture 5 (1), 87 - 94 . Available on line: http://www.unimaid.edu.ng.

[5] Akhigbe, J. (2013). The state and development interventions in the Niger Delta region of Nigeria. International Journal of Humanities and Social Science, 3 (10), 255-263. Retrieved from www.ijhssnet.com.

[6] Ako, R. T. (2012). Re-defining corporate social responsibility (CSR) in Nigeria's post amnesty oil industry. African Journal of Economic and Management Studies, 3, 9-22. doi:10.1108/20400701211197258.
[7] Ako, R. T., Obokoh, L. O., \& Okonmah, P. (2009). Forging peaceful relationships between oil-companies and hostcommunities in Nigeria's Niger Delta region: A stakeholder's perspective to corporate social responsibility. Journal of Enterprising Communities: People and Places in the Global Economy, 2, 205-216. doi: 10.1108/17506200910960888.

[8] Akpabio, E. M., \& Akpan, S. N. (2010). Governance and oil politics in Nigeria's Niger Delta: The question of distributive equity. Journal of Human Ecology, 30, 111-121.

[9] Akpan, U. F., \& Chuku, A. (2011). Economic growth and environmental degradation in Nigeria: beyond the environmental kuznets curve. Munich Personal RePEc Archive. Online at http://mpra.ub.uni-muenchen.de/31241/.

[10] Akpomuvie, O. B. (2011). Tragedy of commons: analysis of oil spillage, gas flaring and sustainable development of the Niger Delta of Nigeria, Journal of Sustainable Development, (2), 200-210. http://dx.doi.org/105539/jsd-v4n2.

[11] Alege, P. O., \& Ogundipe, A. A. (2013). Environmental quality and economic growth in Nigeria: A fractional cointegration analysis. International Journal of Development and Sustainability, 2 (2), 580-596. Retrieved from: www.isdsnet.com/ijds.

[12] Anyakora, C., \& Coker, H. (2009). Assessment of PAH's contamination of ground water: A case study of the Niger Delta region of Nigeria. International Journal of Risk Assessment and Management, 13, 150-170. doi:10.1504/IJRAM.2009.030327.

[13] Araoye, F. E., Ajayi, E. O., Olatunji, T. E., \& Aruwaji, A. M. (2018). Environmental cost accounting: effect of pollution on economic growth in Nigeria. Journal of Accounting and Financial Management, 4 (1), 19-31.

[14] Atakpo, E. A., \& Ayolabi, E. A. (2009). Evaluation of aquifer vulnerability and protective capacity in some oil producing communities of the western Niger Delta. Environmentalist, 29, 310-317. doi:10.1007./s10669-008-9191-3.

[15] Atubi, A. O. (2015). Factors of environmental degradation in oil producing communities of delta state, Nigeria. Journal of Agriculture and Environmental Sciences, 4 (2), 58-70. DOI: 10.15640/jaes.v4n2a7.

[16] Ayoola, T. J. (2011). Gas flaring and its implication for environmental accounting in Nigeria. Journal of Sustainable Development, 4 (5), 244.

[17] Babatunde, A. (2010). The impact of oil exploitation on the socio-economic life of the ilaje-ugbo people of Ondo state, Nigeria. Journal of Sustainable Development in Africa, 12 (5).

[18] Bayode, O. J. A., Adewunmi, E. A. \& Odunwole, S. (2011). Environmental implications of oil exploration and exploitation in the coastal region of Ondo state, Nigeria: a regional planning appraisal. Journal of Geography and Regional Planning, 4 (3), 110-121.

[19] Conwall. J. L. (n.d). Encyclopaedia Britannica. Retrieved from https://www.britannica.com/topic/economic-growth.

[20] Duru, C. U., (2014). Environmental degradation: key challenge to sustainable economic development in the niger delta. Walden Dissertation \& Doctoral Studies Collection, Walden University. Retrieved from http://scholarworks.waldenu.edu/dissertations. 
[21] Edino, M. O., Nsofor, G. N., \& Bombom, L. S. (2010). Perceptions and attitudes towards gas flaring in the Niger Delta, Nigeria. Environmentalist, 30, 67-75. doi:10.1007/s10669-009-9244-2.

[22] Ekpoh, I. J., \& Obia, A. E. (2010). The role of gas flaring in the rapid corrosion of zinc roofs in the Niger Delta region of Nigeria. Environmentalist, 30, 347-352. doi:10.1007/s10669010-9292-7.

[23] Elvidge, C. D., Ziskin, D., Baugh, K. E., Tuttle, B. T., Ghosh, T., Pack, D. W. \& Zhizhin, M. (2009). A fifteen year record of global natural gas flaring derived from satellite data. Energies, $2(3), 595-622$.

[24] Escobar, L. F., \& Vredenburg, H. (2011). Multinational oil companies and the adoption of sustainable development: A resource-based and institutional theory interpretation of adoption heterogeneity. Journal of Business Ethics, 98, 39-65. doi:10.1007/s10551-010-0534-x.

[25] Etuonovbe, A. K. (2009). The devastating effects of environmental degradation - A case study of the Niger Delta region of Nigeria. FIG Working Week, Israel.

[26] Eze, J. C., Nweze, A. U., \& Enekwe, C. I. (2016). The effects of environmental accounting on a developing nation: Nigerian experience. European Journal of Accounting, Auditing and Finance Research, 4 (1), 17-27. Retrieved from www.eajournals.org.

[27] Federal Environmental Protection Agency (1992). Environmental Impact Assessment Act. Retrieved from www.nigerialaw/federalenvironmentalprotectionagency.

[28] Ihayere, C., Ogeleka, D. F., \& Ataine, T. I. (2014). The effects of the Niger Delta oil crisis on women folks. Journal of African Studies and Development, 6 (1), 14-21. doi:10.5897/JASD11.078.

[29] Imobighe, M. D. (2011). Paradox of oil wealth in the nigerdelta region of nigeria: how sustainable is it for national development. Journal of Sustainable Development, 4 (6), 160168.

[30] Jimoh, H. I., Ajewole, O. D., Onotu, S. I., \& Ibrahim, R. O. (2011). Implications of land degradation, reclamations and utilizations in the oil producing areas of Nigeria: Perspectives on environmental sustainability and development. International Journal of Business \& Social Science, 2 (22), 248-254. Retrieved from http://www.Ijbssnet.com/.

[31] Kijima, M., Nishide, K., \& Ohyam, A. (2010). Economic Models for the Environmental Kuznets Curve, Journal of Economic Dynamics\& Control, 34, 1187-1201.

[32] Kingston, K. G. (2011). The dilemma of minerals dependent economy: The case of foreign direct investment and pollution in Nigeria. African Journal of Social Sciences, 1, 1-13. Retrieved from http://mpra.ub.uni-muenchen.de/29046.

[33] Odoemene, A. (2011). Social consequences of environmental change in the Niger Delta of Nigeria. Journal of Sustainable Development, 4 (2), 123-135. doi:10.55539/jsd.v4n2p123.

[34] Ogboru, I., \& Anga, R. A. (2015). Environmental degradation and sustainable economic development in Nigeria: A theoretical approach. Researchjournali's Journal of Economics, 3 (6), 1-13.
[35] Oguduvwe, J. I. P. (2013). Poverty in oil rich Delta: A study of selected oil producing communities in Delta State, Nigeria. Global Research Journal of Education, 3 (1), 1-11. Retrived from http://www.globalresearchjournals.org/journal/grje.

[36] Okpako, J. E. F. (2014). Influence of oil activities on the socio-economic and environmental health of host Niger Delta communities in Nigeria. Mediterranean Journal of Social Sciences, 5 (17), 97-106. Doi:10.5901/mjss.2014.v5n17p97.

[37] Okpara, C. (2012). Right to a clean and healthy environment: The panacea to the Niger Delta struggle. Journal of Politics and Law, 5, 3-8. doi:10.5539/jpl.v5n1p3.

[38] Okpo, O. C., \& Eze, R. C. (2012). Vandalization of oil pipelines in the Delta Niger region of Nigeria, and poverty: An overview. Studies in Sociology of Science, 3 (2), 13-21. doi:10.3968/j.sss.1923018420120302.2950.

[39] Olufemi, O. (2010). Corporate social responsibility of multinational oil corporations to host communities in Niger Delta Nigeria. Ife Psychologia, 18 (2), 21-36. doi:10.4314/ifep.v18i2.56641.

[40] Omojimite, B. U. (2012). Sustainable development, peace and security in the Niger Delta region. European Journal of Social Sciences, 28, 549-558. Retrieved from $\mathrm{http} / / / \mathrm{www}$.europeanjournalofsocialsciences.com.

[41] Omorede, C. K. (2014). Assessment of the impact of oil and gas resource exploration on the environment of selected communities in Delta State, Nigeria. International Journal of Management, Economics and Social Sciences 3 (2), 79-99.

[42] Oyebamiji, M. A., \& Mba, C. I. (2014). Effects of oil spillage on community development in the Niger Delta region: implications for the eradication of poverty and hunger (millennium development goal one) in Nigeria. World Journal of Social Science, 1 (1), 27-36. doi:10.5430/wjss.v1n1p27.

[43] Smulders, S. (2000), Economic Growth and Environmental Quality. Principles of environmental and Resources Economics, Henk Folmer and Landis Gabel (eds), Edward Elgar.

[44] Sonibare, J. A., Adebeyi, F. M., Obanijesu, E. O., \& Okelana, O. A. (2010). Air quality index pattern around petroleum production facilities. Management of Environmental Quality, 21,379-392. doi: 10.1108/14777831011036920.

[45] Uchegbu, S. N. (1988). Environmental Management and Protection. Enugu, NG: Spotlite Publishers.

[46] Uchegbu, S. N. (2002). Environmental Management and Protection. Enugu, NG: Precision Printers and Publishers.

[47] Ukpong, S. J. (1994). Global and Nigerian Environment Problem analysis. Calabar, NG: SIRF.

[48] United Nations Environment Program. (2011). Environmental assessment of Ogoniland report. Retrieved from http://www.unep.org/Nigeria.

[49] Wikipedia, (2018). Economic growth. Retrieved from https://en.wikipedia.org/w/index.php?title=Economic_growth \&oldid $=848026687$.

[50] World Bank (1991). Environmental Assessment Source Book. Washington D. C. World Bank. Tech. Pap., p. 139. 